\title{
KEMAMPUAN SISWA DALAM PEMBELAJARAN MENULIS PUISI BEBAS BERTEMA BENCANA SULAWESI TENGAH (SULTENG) PADA SISWA KELAS V SDN BULURI PALU
}

\author{
Rani Fardani \\ Program Studi Bahasa dan Sastra Indonesia, Fakultas Sastra, Universitas Alkhairaat Palu \\ rani_unisa@yahoo.co.id
}

\begin{abstract}
ABSTRAK
Penelitian ini bertujuan untuk mengetahui: (1) Bagaimana kemampuan siswa kelas V SDN Buluri Palu dalam menentukan gagasan pokok pada pembelajaran menulis puisi bebas bertema bencana Sulawesi Tengah (Sulawesi Tengah), (2) Bagaimana kemampuan siswa secara kreatif dalam menggunakan pilihan kata/ diksi yang tepat pada pembelajaran menulis puisi bebas bertema bencana Sulawesi Tengah, (3) Bagaimana kemampuan siswa dalam pembelajaran menulis puisi bebas bertema bencana Sulawesi Tengah. Metode yang digunakan dalam penelitian ini adalah deskriptif kualitatif, dengan subjek penelitian adalah semua siswa kelas V di SDN Buluri sebanyak 29 siswa. Berdasarkan analisis, hasil menunjukkan bahwa, (1)Dalam menentukan gagasan pokok puisi bebas bertema bencana Sulawesi Tengah, siswa kelas V dikatakan mampu, karena dari 29 siswa diperoleh kualifikasi sangat tepat yakni 3 siswa (10,34\%), kualifikasi tepat 23 siswa (79,32\%), kualifikasi kurang tepat (0\%), kualifikasi tidak tepat 3 siswa (10,34\%). (2)Dalam aspek menggunakan pilihan kata/ diksi, siswa kelas V dikatakan tidak mampu, karena dari 29 siswa diperoleh kualifikasi sangat tepat yakni 3 siswa (10,34\%), kualifikasi tepat 7 siswa $(24,14 \%)$, kualifikasi kurang tepat 8 siswa (27,59\%), kualifikasi tidak tepat 11 siswa (37,93\%), (3)Secara umum dapat dijelaskan bahwa siswa kelas V belum mampu menulis puisi bebas bertema bencana Sulawesi Tengah. Hal ini dibuktikan dengan perolehan siswa kelas V, dari 29 siswa, 5 siswa $(17,24 \%)$ mampu menulis puisi bebas bertema bencana Sulawesi Tengah, sedangkan 24 siswa (82,76\%) tidak dapat menulis puisi bebas bertema bencana Sulawesi Tengah.
\end{abstract}

Kata kunci: Menulis, Puisi bebas, Siswa.

\begin{abstract}
This study aims to find out: (1) How is the ability of fifth-grade students at Elementary School in Buluri Palu to determine the main ideas of making poetry about Central Sulawesi disaster (Central Sulawesi), (2) How is the ability of students to use the right choice of words/ diction based on the creativity of the Central Sulawesi disaster theme, (3) How is the ability of students in learning to write free poetry with the theme of Central Sulawesi disaster. The method used in this study was descriptive qualitative, with the subject of the study were all of the fifth-grade students in Buluri Elementary School consisted of 29 students. Based on the analysis, the results showed that, (1) In determining the poetry main ideas with the Central Sulawesi disaster theme, fifth-grade students were said to be capable, because of the 29 students obtained very precise qualifications of 3 students (10.34\%), 23 students were qualified correctly (79.32\%), the qualifications are not quite right $(0 \%)$, the qualifications are not exactly 3 students (10.34\%). (2) In the aspect of using word/diction, fifth-grade students are said to be unable, because of the 29 students who received very precise qualifications 3 students (10.34\%), the right qualifications were 7 students $(24.14 \%)$, the qualifications were not exactly 8 students (27.59\%), improper qualifications were 11 students (37.93\%). (3)Generally, this study can be described that fifth-grade students have not been able to write free poetry with the theme of the Central Sulawesi disaster. This is evidenced by the acquisition of fifth-grade students, from 29 students, 5 students (17.24\%) were able to write poetry with the theme of Central Sulawesi disaster, while 24 students $(82.76 \%)$ were unable to write poetry with the theme of Central Sulawesi disaster.
\end{abstract}

Keywords: Writing, Free Poetry, Student 


\section{PENDAHULUAN}

Menulis adalah salah satu keterampilan berbahasa produktif yang harus dimiliki siswa, karena dipergunakan untuk berkomunikasi secara tidak langsung, Dalam menulis, seseorang dapat menulis hal apa saja, baik menulis artikel, menulis novel, menulis cerpen, atau menulis puisi. Keterampilan menulis tidak datang secara otomatis, namun harus melalui latihan dan praktek yang teratur, sehingga Henry Guntur Tarigan (2008) berpendapat bahwa menulis merupakan suatu ciri orang yang terpelajar atau bangsa yang terpelajar.

Dalam Kamus Besar Bahasa Indonesia (2008), pengertian menulis adalah melahirkan pikiran atau perasaan (seperti mengarang, membuat surat) dengan tulisan. Menulis berarti menuangkan isi hati si penulis ke dalam bentuk tulisan, sehingga maksud hati penulis bisa diketahui banyak orang orang melalui tulisan yang dituliskan. Kemampuan seseorang dalam menuangkan isi hatinya ke dalam sebuah tulisan sangatlah berbeda, dipengaruhi oleh latar belakang penulis.

Menurut Tampubolon (2007), kemampuan adalah kapasitas kesanggupan atau kecakapan seorang individu dalam melakukan sesuatu hal atau beragam tugas dalam suatu pekerjaan tertentu. Senada dengan Anggiat dan Sri (2001), kemampuan sebagai suatu dasar seseorang yang dengan sendirinya berkaitan dengan pelaksanaan pekerjaan secara efektif atau sangat berhasil, atau kapasistas seseorang individu untuk melakukan beragam tugas dalam suatu pekerjaan. Dalam hal ini, jika dihubungkan dengan kemampuan siswa maka dapat diartikan kemampuan siswa adalah kesanggupan siswa melakukan sesuatu hingga mencapai keberhasilan.

Dalam kaitannya dengan kemampuan menulis, keberhasilan siswa dalam menulis tidak lepas dari proses pembelajaran yang merupakan proses bertahap dan terstruktur melalui pengalaman belajar langsung siswa. Pembelajaran merupakan proses terarah yang diberikan guru terhadap peserta didik agar dapat terjadi proses transfer ilmu pengetahuan, pembentukan sikap dan kepercayaan pada peserta didik. Menurut Hamdani (2011), "Pembelajaran adalah upaya guru menciptakan iklim dan pelayanan terhadap kemampuan, potensi, minat, bakat, dan kebutuhan siswa yang amat beragam agar terjadi interaksi optimal antara guru dan siswa serta antar-siswa." Lebih lanjut lagi, Sudarsosno (2000) berpendapat bahwa "Pembelajaran merupakan bantuan yang diberikan guru agar dapat terjadi proses perolehan ilmu pengetahuan, penguasaan kemahiran serta pembentukan sikap dan kepercayaan pada siswa.

Dalam pembelajaran di sekolah dasar, terkhusus Bahasa Indonesia terdapat kompetensi dasar menulis puisi bebas dengan menentukan gagasan pokok berdasarkan pengalaman, dan menggunakan pilihan kata yang tepat pada semester genap tahun pelajaran 2018/2019. Tujuan yang diharapkan dalam pembelajaran menulis puisi bebas bertema bencana Sulteng ini adalah siswa dapat menentukan gagasan pokok berdasarkan pengalaman, dan menggunakan pilihan kata (diksi) yang tepat sehingga menjadi puisi yang utuh.

Menurut Djojosuroto (2006), puisi merupakan ekspresi dari pengalaman imajinatif manusia. Puisi juga dapat mengekspresikan pikiran yang dapat membangkitkan perasaan yang dapat merangsang imajinasi panca indera dalam susunan yang berirama. Semua itu merupakan sesuatu yang penting yang dapat direkam dan diekspresikan dan dinyatakan dengan menarik dan memberi kesan. Sesuai juga dengan pendapat Pradopo (2007) yang menyatakan bahwa puisi merupakan rekaman dan interprestasi pengalaman manusia yang penting, digubah dalam wujud yang paling berkesan. Jadi, puisi pada dasarnya merupakan karya satra yang mengungkapkan perasaan yang kongkret dan bersifat artistik/estetis/bernilai seni keindahan yang beraal dari pikiran manusia tercipta karena emosional penyairnya yang dituangkan dalam kekuatan bahasa.

Menulis puisi adalah salah satu kegiatan seseorang untuk mengungkapkan perasaannya melalui tulisan. Bahasa yang digunakan dalam menulis puisi berbeda dengan bahasa yang digunakan sehari-hari. Jabrohim (2009) berpendapat bahwa "menulis puisi merupakan suatu kegiatan seorang intelektual, yakni kegiatan yang 
menuntut seseorang harus benar-benar cerdas, harus benar-benar menguasai bahasa, luas wawasannya, sekaligus peka perasaannya." Kemampuan menulis puisi sering dianggap sebagai bakat, sehingga orang yang merasa tidak mempunyai bakat tidak dapat menulis puisi. Anggapan seperti itu tidak selalu benar karena bakat yang tidak dilatih juga akan hilang. Menulis puisi hanya perlu rajin belajar dan terus berlatih agar terampil dalam menulis puisi sehingga akan terasah kemampuan siswa.

Sesuai dengan kompetensi dasar Bahasa Indonesia pada pembelajaran menulis pusi bebas, maka dapat dideskripsikan bahwa puisi bebas adalah puisi yang tidak terikat oleh aturan-aturan bait, baris, dan rima (Waluyo, 2002), atau dengan kata lain puisi bebas adalah puisi tanpa ikatan dari aturanaturan pembuatan puisi contohnya puisi karangan Chairil Anwar, Taufik Ismail dan sebagainya. Disambung pula oleh Waluyo (2002) bahwa ciri-ciri puisi bebas adalah: (1)bentuknya bebas, tetapi mengutamakan ekspresi jiwa, (2)penulisannya cenderung eksperimen, (3)tata tulisnya (tipografi) tidak mendukung keindahan, tetapi juga membantu imajinasi, (4)setiap kata atau bunyi diusahakan mendukung makna, membangkitkan imajinasi dan bernilai estetis.

Demikian halnya pada siswa kelas V di SDN Buluri Palu, kemampuan menulis puisi bebas bertema bencana Sulteng masih kurang dan belum mampu dilakukan. Dengan melihat kenyataan tersebut, penelitian ini untuk mendeskripsikan kemampuan siswa dalam pembelajaran menulis puisi bebas bertema bencana sulawesi tengah (Sulteng).

\section{METODE PENELITIAN}

Penelitian menggunakan pendekatan deskriptif kualitatif bertujuan untuk mendeskripsikan kemampuan siswa kelas $\mathrm{V}$ dalam pembelajaran menulis puisi bebas bertema bencana Sulteng di SDN Buluri Palu. Adapun yang menjadi subjek penelitian ini adalah seluruh siswa kelas V di SDN Buluri Palu yang berjumlah 29 orang. Laki-laki berjumlah 10 orang dan perempuan berjumlah 19 orang.

Data dikumpulkan melalui teknik:

\section{a. Observasi}

Pada tahap observasi, peneliti mengamati keadaan siswa kelas V SDN Buluri Palu dalam menulis puisi, dengan memperhatikan indikator yang ditentukan. Adapun indikator dimaksud yaitu: (1) mampu menentukan gagasan pokok puisi, (2) mampu menentukan pilihan kata, dan (3) mampu merangkai kata dalam puisi sehingga menjadi puisi yang utuh.

b. Tes Kemampuan

Data penelitian diperoleh dengan menggunakan tes kemampuan menulis puisi bebas bertema bencana Sulteng.

Adapun cara menilai puisi menurut Zaini Machmoed (dalam Nurgiyantoro, 2009), yakni menggunakan penilaian dengan berpedoman pada indikator-indikator dalam membuat puisi. Indikator- indikator yang dimaksud antara lain: (1)menentukan gagasan pokok puisi, (2)menentukan pilihan kata, (3)merangkai kata sehingga menjadi puisi yang utuh. Untuk lebih jelasnya dapat dilihat melalui tabel berikut.

Tabel 1. Aspek yang dinilai.

\begin{tabular}{lll}
\hline No & \multicolumn{1}{c}{ Aspek Penilaian } & \multicolumn{2}{c}{ Indikator } \\
\hline $1 \quad$ Menentukan gagasan pokok puisi. & a. & skor 4= apabila gagasan pokok yang ditentukan \\
a. Sangat tepat (4) & sesuai dengan tema bencana Sulteng dan \\
b. Tepat (3) & menyebutkan dengan jelas judul puisi yang \\
c. Kurang tepat (2) & berhubungan dengan tema. \\
d. Tidak tepat (1) & b. $\begin{array}{l}\text { skor 3= apabila gagasan pokok yang ditentukan } \\
\text { sesuai dengan tema bencana Sulteng, tapi tidak } \\
\end{array}$ & menyebutkan dengan jelas judul puisi yang \\
& berhubungan dengan tema. \\
& c. skor 2= apabila gagasan pokok yang ditentukan \\
& berhubungan dengan tema bencana Sulteng, tapi \\
& bukan tema bencana Sulteng.
\end{tabular}


d. skor 1= apabila gagasan pokok yang ditentukan tidak berhubungan dengan tema bencana Sulteng atau tidak menentukan judul puisi.

2 Menentukan pilihan kata dalam membuat puisi.
a. Sangat tepat (8)
b. Tepat (7)
c. Kurang tepat (6)
d. Tidak tepat (5)

3 Mampu merangkai kata-kata sehingga menjadi sebuah puisi.
a. Sangat baik (4)
b. Baik (3)
c. Kurang baik (2)
d. Tidak baik (1)

a. skor $8=$ apabila diksi yang ditentukan berhubungan dengan tema dan judul puisi, serta diksi yang ditentukan minimal 8-10 diksi.

b. skor $7=$ apabila diksi yang ditentukan berhubungan dengan tema dan judul puisi, serta diksi yang ditentukan minimal 5-7 diksi.

c. skor $6=$ apabila diksi yang ditentukan berhubungan dengan tema dan judul puisi, serta pilihan kata minimal 2-4 diksi.

d. skor $5=$ tidak menentukan diksi.

a. skor 4= memiliki kesesuaian antara larik satu dengan larik yang lain, penggunaan huruf kapital benar, penulisan singkatan benar, penulisan kata depan dan kata hubung benar.

b. skor $3=$ memiliki kesesuaian antara larik satu dengan larik lain, penggunaan huruf kapital salah, penulisan singkatan benar, penulisan kata depan dan kata hubung benar.

c. skor $2=$ memiliki kesesuaian antara larik satu dengan larik lain, penggunaan huruf kapital salah, penulisan singkatan salah, penulisan kata depan dan kata hubung salah.

d. skor $1=$ tidak sesuai antara larik satu dengan larik lain, penggunaan huruf kapital
Setelah hasil pekerjaan setiap siswa dinilai, maka nilai siswa tersebut diklasifikasi sesuai tingkat kemampuan menggunakan pedoman di sekolah tempat meneliti. Kemampuan siswa diklasifikasikan ke dalam empat bagian, yaitu baik sekali, baik, cukup, dan kurang. Siswa dikatakan mampu jika klasifikasi kemampuan ditingkat penguasaan dari 70\%-100\%, sedangkan dikatakan belum mampu jika klasifikasi kemampuan ditingkat penguasaan dari 0\%-69\% dengan nilai acuan patokan di bawah ini:

Tabel 2. Penilaian Acuan Patokan.

\begin{tabular}{ccc}
\hline Nilai yang diperoleh & Interval persentase tingkat penguasaan & Ket. \\
\hline $90-100$ & $90 \%-100 \%$ & Baik sekali \\
$80-89$ & $80 \%-89 \%$ & Baik \\
$70-79$ & $70 \%-79 \%$ & Cukup \\
$0-69$ & $0 \%-69 \%$ & Kurang \\
\hline
\end{tabular}

\section{Keterangan:}

a. Siswa yang memperoleh capaian nilai antara 90-100 atau termasuk dalam kualifikasi baik sekali yaitu jika siswa tersebut mendapat jumlah skor 15 sampai 16 dari keempat aspek yang dinilai.

b. Siswa yang memperoleh capaian nilai antara 80-89 atau termasuk dalam kualifikasi baik yaitu jika siswa tersebut mendapat jumlah skor 13 sampai 14 dari keempat aspek yang dinilai.

c. Siswa yang memperoleh capaian nilai antara 70-79 atau termasuk dalam kualifikasi cukup yaitu jika siswa tersebut mendapat jumlah skor 12 dari keempat aspek yang dinilai.

d. Siswa yang memperoleh capaian nilai antara 0-69 atau termasuk dalam 
kualifikasi kurang yaitu jika siswa tersebut mendapat jumlah skor 4 sampai 11 dari keempat aspek yang dinilai.

\section{HASIL DAN PEMBAHASAN}

Kemampuan siswa kelas V SDN Buluri dalam menentukan gagasan pokok puisi bertema bencana Sulteng, dengan indikator: skor $4=$ apabila gagasan pokok yang ditentukan sesuai dengan tema bencana Sulteng dan menyebutkan dengan jelas judul puisi yang berhubungan dengan tema; skor $3=$ apabila gagasan pokok yang ditentukan sesuai dengan tema bencana Sulteng, tapi tidak menyebutkan dengan jelas judul puisi yang berhubungan dengan tema; skor $2=$ apabila gagasan pokok yang ditentukan berhubungan dengan tema bencana Sulteng, tapi bukan tema tema bencana Sulteng; skor $1=$ apabila gagasan pokok yang ditentukan tidak berhubungan dengan tema bencana Sulteng atau tidak menentukan judul puisi. Adapun hasil uji kemampuan siswa kelas V SDN Buluri Palu dalam menentukan gagasan pokok puisi disajikan melalui tabel berikut:

Tabel 3. Hasil Uji Kemampuan Siswa dalam Menentukan Gagasan Pokok Puisi

\begin{tabular}{clcl}
\hline No. & Nama Siswa & Skor & Predikat \\
\hline 1 & Alen & 1 & Tidak Tepat \\
2 & Andi Nuraeni & 3 & Tepat \\
3 & Anum & 3 & Tepat \\
4 & Cesya Afriani & 3 & Tepat \\
5 & Fahri & 3 & Tepat \\
6 & Febriansyah Ilham & 3 & Tepat \\
7 & Ica Handayani & 3 & Tepat \\
8 & Ira Lestari & 3 & Tepat \\
9 & Keila & 1 & Tidak Tepat \\
10 & Mivta Ayu & 4 & Sangat Tepat \\
11 & Moh.Alfahri & 3 & Tepat \\
12 & Moh Fajri Pratama & 3 & Tepat \\
13 & Muh Azril & 3 & Tepat \\
14 & Nabila Putri & 3 & Tepat \\
15 & Nadia Olivia & 3 & Tepat \\
16 & Nur Amanah & 3 & Tepat \\
17 & Nur Aziza & 3 & Tepat \\
18 & Ramdany & 3 & Tepat \\
19 & Ridho & 3 & Tepat \\
20 & Robi'ah Syafira & 3 & Tepat \\
21 & Roni & 3 & Tepat \\
22 & Selsiasari & 3 & Tepat \\
23 & Siren & 4 & Sangat Tepat \\
24 & Siti Alvian & 3 & Tepat \\
25 & Siti Fanila & 1 & Tidak Tepat \\
26 & Siti Kalsum & 3 & Tepat \\
27 & Sri Ningsi & 3 & Tepat \\
28 & Zahra Febrianti & 4 & Sangat Tepat \\
29 & Aswad & 3 & Tepat \\
\hline & & & \\
& &
\end{tabular}

Tabel di atas tampak bahwa siswa mampu menentukan gagasan pokok puisi. Dari 29 siswa yang memperoleh kualifikasi sangat tepat 3 siswa $(10,34 \%)$, kualifikasi tepat 23 siswa $(79,32 \%)$, kualifikasi kurang tepat tidak ada, kualifikasi tidak tepat 3 siswa $(10,34 \%)$.

Kemampuan siswa menggunakan diksi berdasarkan kreatifitas ungkapan perasaan bertema bencana Sulteng, dengan indikator: skor $8=$ apabila diksi yang ditentukan 
berhubungan dengan tema dan judul puisi, serta diksi yang ditentukan minimal 8-10 diksi: skor $7=$ apabila diksi yang ditentukan berhubungan dengan tema dan judul puisi, serta diksi yang ditentukan minimal 5-7 diksi; skor $6=$ apabila diksi yang ditentukan berhubungan dengan tema dan judul puisi, serta pilihan kata minimal 2-4 diksi; skor 5= tidak menentukan diksi. Adapun hasil uji kemampuan siswa dalam menggunakan pilihan kata/diksi puisi disajikan melalui tabel berikut:

Tabel 4. Hasil Uji Kemampuan Siswa dalam Menggunakan Diksi

\begin{tabular}{clcl}
\hline No. & Nama Siswa & Skor & \multicolumn{1}{c}{ Predikat } \\
\hline 1 & Alen & 8 & Sangat Tepat \\
2 & Andi Nuraeni & 7 & Tepat \\
3 & Anum & 5 & Tidak Tepat \\
4 & Cesya Afriani & 7 & Tepat \\
5 & Fahri & 6 & Kurang Tepat \\
6 & Febriansyah Ilham & 6 & Kurang Tepat \\
7 & Ica Handayani & 8 & Sangat Tepat \\
8 & Ira Lestari & 5 & Tidak Tepat \\
9 & Keila & 5 & Tidak Tepat \\
10 & Mivta Ayu & 6 & Kurang Tepat \\
11 & Moh.Alfahri & 6 & Kurang Tepat \\
12 & Moh Fajri Pratama & 5 & Tidak Tepat \\
13 & Muh Azril & 5 & Tidak Tepat \\
14 & Nabila Putri & 5 & Tidak Tepat \\
15 & Nadia Olivia & 7 & Tepat \\
16 & Nur Amanah & 7 & Tepat \\
17 & Nur Aziza & 8 & Sangat Tepat \\
18 & Ramdany & 6 & Kurang Tepat \\
19 & Ridho & 7 & Tepat \\
20 & Robi'ah Syafira & 7 & Tepat \\
21 & Roni & 7 & Tepat \\
22 & Selsiasari & 6 & Kurang Tepat \\
23 & Siren & 5 & Tidak Tepat \\
24 & Siti Alvian & 5 & Tidak Tepat \\
25 & Siti Fanila & 5 & Tidak Tepat \\
26 & Siti Kalsum & 6 & Kurang Tepat \\
27 & Sri Ningsi & 5 & Tidak Tepat \\
28 & Zahra Febrianti & 6 & Kurang Tepat \\
29 & Aswad & 5 & Tidak Tepat \\
\hline & & & \\
\hline
\end{tabular}

Tabel 3 menunjukkan bahwa siswa kelas $\mathrm{V}$ belum mampu menentukan pilihan kata. Hal ini dilihat dari 29 siswa yang memperoleh kualifikasi sangat tepat 3 siswa $(10,34 \%)$, kualifikasi tepat 7 siswa $(24,14 \%)$, kualifikasi kurang tepat 8 siswa $(27,59 \%)$ dan kualifikasi tidak tepat 11 siswa $(37,93 \%)$.

Kombinasi antara menentukan gagasan pokok dengan penggunaan diksi akan mempengaruhi siswa dalam merangkai kata, sehingga diperoleh hasil uji terhadap kemampuan merangkai kata menjadi puisi yang utuh, dengan indikator: skor $4=$ memiliki kesesuaian antara larik satu dengan larik yang lain, penggunaan huruf kapital benar, penulisan singkatan benar, penulisan kata depan dan kata hubung benar; skor 3= memiliki kesesuaian antara larik satu dengan larik lain, penggunaan huruf kapital salah, penulisan singkatan benar, penulisan kata depan dan kata hubung benar; skor 2= memiliki kesesuaian antara larik satu dengan larik lain, penggunaan huruf kapital salah, penulisan singkatan salah, penulisan kata depan dan kata hubung salah; skor $1=$ tidak sesuai antara larik satu dengan larik lain, 
penggunaan huruf kapital, dan disajikan pada tabel berikut:

Tabel 5. Hasil Uji Kemampuan Siswa dalam Merangkai Kata menjadi Puisi Utuh

\begin{tabular}{clcl}
\hline No. & Nama Siswa & Skor & Predikat \\
\hline 1 & Alen & 2 & kurang baik \\
2 & Andi Nuraeni & 1 & tidak baik \\
3 & Anum & 1 & tidak baik \\
4 & Cesya Afriani & 1 & tidak baik \\
5 & Fahri & 1 & tidak baik \\
6 & Febriansyah Ilham & 1 & tidak baik \\
7 & Ica Handayani & 4 & sangat baik \\
8 & Ira Lestari & 2 & kurang baik \\
9 & Keila & 1 & tidak baik \\
10 & Mivta Ayu & 2 & kurang baik \\
11 & Moh.Alfahri & 1 & tidak baik \\
12 & Moh Fajri Pratama & 1 & tidak baik \\
13 & Muh Azril & 1 & tidak baik \\
14 & Nabila Putri & 1 & tidak baik \\
15 & Nadia Olivia & 1 & tidak baik \\
16 & Nur Amanah & 2 & kurang baik \\
17 & Nur Aziza & 2 & kurang baik \\
18 & Ramdany & 1 & tidak baik \\
19 & Ridho & 1 & tidak baik \\
20 & Robi'ah Syafira & 2 & kurang baik \\
21 & Roni & 1 & tidak baik \\
22 & Selsiasari & 2 & kurang baik \\
23 & Siren & 2 & kurang baik \\
24 & Siti Alvian & 3 & Baik \\
25 & Siti Fanila & 1 & tidak baik \\
26 & Siti Kalsum & 2 & kurang baik \\
27 & Sri Ningsi & 1 & tidak baik \\
28 & Zahra Febrianti & 1 & tidak baik \\
29 & Aswad & 1 & tidak baik \\
\hline & & & \\
& & &
\end{tabular}

Dari tabel di atas tampak bahwa siswa kelas $\mathrm{V}$ belum mampu merangkai kata menjadi puisi yang utuh. Hal ini dilihat dari 29 siswa yang memperoleh kualifikasi sangat baik 1 siswa $(3,45 \%)$, kualifikasi baik 1 siswa $(3,45 \%)$, kualifikasi kurang baik 9 siswa $(31,03 \%)$, dan kualifikasi tidak baik 18 siswa $(62,07 \%)$.

Kemampuan siswa dalam pembelajaran menulis puisi bebas bertema bencana Sulteng, dengan kualifikasi: baik sekali, baik, cukup, dan kurang. Siswa dikatakan mampu jika klasifikasi kemampuan ditingkat penguasaan dari 70\%$100 \%$, sedangkan dikatakan belum mampu jika klasifikasi kemampuan ditingkat penguasaan dari 0\%-69\%. Adapun hasil uji kemampuan siswa dalam pembelajaran menulis puisi bebas bertema bencana Sulteng pada siswa kelas V SDN Buluri Palu dengan pertimbangan 3 indikator di atas, dideskripsikan sebagai berikut.

Tabel 6. Hasil Uji Kemampuan Siswa dalam Pembelajaran Menulis Puisi Bebas

\begin{tabular}{clccccc}
\hline No. & Nama Siswa & & Indikator & & Capaian & Predikat \\
& & $\mathbf{1}$ & $\mathbf{2}$ & $\mathbf{3}$ & & \\
\hline 1 & Alen & 1 & 8 & 2 & 68 & belum mampu \\
2 & Andi Nuraeni & 3 & 7 & 1 & 68 & belum mampu
\end{tabular}




\begin{tabular}{lllllll}
3 & Anum & 3 & 5 & 1 & 56 & belum mampu \\
4 & Cesya Afriani & 3 & 7 & 1 & 68 & belum mampu \\
5 & Fahri & 3 & 6 & 1 & 62 & belum mampu \\
6 & Febriansyah Ilham & 3 & 6 & 1 & 62 & belum mampu \\
7 & Ica Handayani & 3 & 8 & 4 & 93 & mampu \\
8 & Ira Lestari & 3 & 5 & 2 & 62 & belum mampu \\
9 & Keila & 1 & 5 & 1 & 43 & belum mampu \\
10 & Mivta Ayu & 4 & 6 & 2 & 75 & mampu \\
11 & Moh.Alfahri & 3 & 6 & 1 & 62 & belum mampu \\
12 & Moh Fajri Pratama & 3 & 5 & 1 & 56 & belum mampu \\
13 & Muh Azril & 3 & 5 & 1 & 56 & belum mampu \\
14 & Nabila Putri & 3 & 5 & 1 & 56 & belum mampu \\
15 & Nadia Olivia & 3 & 7 & 1 & 68 & belum mampu \\
16 & Nur Amanah & 3 & 7 & 2 & 75 & mampu \\
17 & Nur Aziza & 3 & 8 & 2 & 81 & Mampu \\
18 & Ramdany & 3 & 6 & 1 & 62 & belum mampu \\
19 & Ridho & 3 & 7 & 1 & 68 & belum mampu \\
20 & Robi'ah Syafira & 3 & 7 & 2 & 75 & Mampu \\
21 & Roni & 3 & 7 & 1 & 68 & belum mampu \\
22 & Selsiasari & 3 & 6 & 2 & 68 & belum mampu \\
23 & Siren & 4 & 5 & 2 & 68 & belum mampu \\
24 & Siti Alvian & 3 & 5 & 3 & 68 & belum mampu \\
25 & Siti Fanila & 1 & 5 & 1 & 43 & belum mampu \\
26 & Siti Kalsum & 3 & 6 & 2 & 68 & belum mampu \\
27 & Sri Ningsi & 3 & 5 & 1 & 56 & belum mampu \\
28 & Zahra Febrianti & 4 & 6 & 1 & 68 & belum mampu \\
29 & Aswad & 3 & 5 & 1 & 56 & belum mampu \\
\hline
\end{tabular}

Dari tabel di atas dapat disimpulkan bahwa siswa kelas V SDN Buluri Palu dalam pembelajaran menulis puisi bebas bertema bencana Sulteng dari 29 siswa dapat dikategorikan belum mampu sebab ada 24 siswa $(82,76 \%)$ belum mampu menulis puisi bebas sedangkan hanya ada 5 siswa $(17,24$ $\%$ ) dapat dikategorikan mampu menulis puisi bebas bertema bencana Sulteng.

\section{KESIMPULAN}

Berdasarkan hasil pembahasan penelitian di atas, maka dapat disimpulkan:

1. Kemampuan siswa kelas V SDN Buluri Palu dalam menentukan gagasan pokok puisi bertema bencana Sulteng dapat dikatakan mampu membuatnya dengan angka mencapai 89,66 \% siswa.

2. Kemampuan siswa menggunakan pilihan kata/diksi yang tepat bertema bencana Sulteng, masih dikategorikan belum mampu karena hanya mencapai $65,52 \%$ siswa yang dapat menggunakan pilihan kata dengan tepat.
3. Kemampuan siswa dalam pembelajaran menulis puisi bebas bertema bencana Sulteng perlu ditingkatkan lagi karena mencapai $82,76 \%$ yang belum mampu membuat puisi bebas bertema bencana Sulteng secara utuh.

\section{SARAN}

Berdasarkan hasil penelitian tentang pembelajaran menulis puisi bebas bertema bencana Sulteng, peneliti menyarakan:

1. Agar guru perlu meningkatkan lagi pembiasaan keterampilan menulis terkhusus puisi.

2. Perlu melakukan pembelajaran Bahasa Indonesia di luar kelas disesuaikan dengan tema pembelajaran sehingga para siswa dapat memperoleh pengalamanpengalaman belajar secara langsung yang dapat menambah wawasan berpikir mereka. 


\section{DAFTAR PUSTAKA}

Anggiat, M Sinaga \& Sri Hadiati. (2001). Kemampuan Menulis Kalimat. Jakarta: Diksi Insan Mulia.

Burhan Nurgiyantoro. (2009). Penilaian dalam Pengajaran Bahasa dan Sastra (Edisi ketiga cetakan kedua). Yogyakarta: BPFE.

Djojosuroto Kinayati. (2006). Pengajaran Puisi: Analisis dan Pemahaman. Bandung: Nuansa.

Hamdani. (2011). Strategi Belajar Mengajar. Bandung: Pustaka Setia.

Henry Guntur Tarigan. (2008). Menulis sebagai Suatu Keterampilan Berbahasa. Bandung: Angkasa.

Jabrohim. (2009). Pengajaran Sastra. Yogyakarta: Pustaka Belajar.

Pradopo, Rachmat Djoko. (2007). Prinsipprinsip Kritik Sastra: Teori dan Penerapannya. Yogyakarta: Gadjah Mada University Press.

Pusat Bahasa. (2008). Kamus Besar Bahasa Indonesia. Jakarta: Gramedia Pustaka Utama.

Sudarsono. (2000). Keterampilan Belajar Mengajar. Jakarta: Bumi Aksara.

Tampubolon, Ahmad. (2007). Kemampuan Berbahasa Indonesia. Jakarta: Rineka Cipta.

Waluyo, Herman J. (2002). Teori dan Apresisai Puisi. Jakarta: Erlangga 